\title{
Proteinuria in a Crohn's disease patient: Questions
}

\author{
Eda Didem Kurt-Sukur • Z. Birsin Özçakar • \\ Songül Yılmaz • Semanur Özdel • Zarife Kuloğlu • \\ Mesiha Ekim • Aydan Kansu • Fatoș Yalçınkaya
}

Received: 26 June 2014 / Revised: 26 June 2014 / Accepted: 27 June 2014 / Published online: 22 August 2014

(C) IPNA 2014

Keywords Crohn's disease $\cdot$ Proteinuria $\cdot$ Familial mediterranean fever $\cdot$ Amyloidosis $\cdot$ Mesalazine

\section{Case presentation}

A 14-year-old girl with the diagnosis of Crohn's disease (CD) who was being followed up at pediatric gastroenterology outpatient clinic of our university was referred to our department due to positive results for spot urinary protein-creatinine.

Her first complaints started at the age of 11 years and consisted of episodes of abdominal pain which were mainly epigastric in nature, occurring at least twice a month, with each episode lasting 3-4 days and accompanied by flatulence and prevalent diarrhea. The episodes were accompanied by fever. With each attack she also had painful joints, once in one shoulder, another time in the knee or pelvis, among other locations, although she never experienced any redness or swelling of her joints. She was first admitted to our hospital with these complaints at age 11.5 years. Her family history revealed no significant health problems and consanguinity was not present. At admittance her body weight and height were less than the third percentile. Physical examination was normal. Laboratory tests were normal except for an elevated erythrocyte sedimentation rate (ESR) of $48 \mathrm{~mm} / \mathrm{h}$

The answers to these questions can be found at http://dx.doi.org/10.1007/ s00467-0142902-8.

E. D. Kurt-Sukur · Z. B. Özçakar · S. Yılmaz · S. Özdel • M. Ekim •

F. Yalçınkaya $(\triangle)$

Division of Pediatric Rheumatology \& Nephrology, Ankara

University School of Medicine, 06530 Ankara, Turkey

e-mail: fyalcin@medicine.ankara.edu.tr

Z. Kuloğlu • A. Kansu

Division of Pediatric Gastroenterology, Ankara University School

of Medicine, Ankara, Turkey (normal range $0-25 \mathrm{~mm} / \mathrm{h}$ ) and elevated C-reactive protein (CRP) $(64.1 \mathrm{mg} / \mathrm{L}$; normal range $0-3 \mathrm{mg} / \mathrm{L})$. Endoscopy and colonoscopy results were normal. Histopathology showed focal active colitis. Taken together, these findings were suggestive of inflammatory bowel disease, especially Crohn's disease. Therapy with mesalazine was started. This treatment was beneficial, and abdominal pain decreased in frequency and duration. At a routine clinical examination during the third year of her routine follow-up, urine analysis revealed $100 \mathrm{mg} / \mathrm{dL}\left(6.2 \mathrm{mg} / \mathrm{m}^{2} / \mathrm{h}\right)$ proteinuria. Laboratory examination at this time showed hemoglobin at $11.2 \mathrm{~g} / \mathrm{dL}$, a white blood cell count of $12,100 / \mathrm{mm}^{3}$ and normal renal function tests with a serum albumin of $4 \mathrm{~g} / \mathrm{dL}$ (normal range 3.8$5.4 \mathrm{~g} / \mathrm{dL}$ ), ESR of $82 \mathrm{~mm} / \mathrm{h}$ and CRP of $51.2 \mathrm{mg} / \mathrm{L}$. Her medical chart was retrospectively analyzed, and we found that her acute phase reactants were above the expected range at most of her previous visits, with the ESR ranging between 26 and $82 \mathrm{~mm} / \mathrm{h}$ and the CRP ranging between 7 and $72 \mathrm{mg} / \mathrm{L}$. No abnormalites were visible on her urinary system ultrasound scan. The patient was then lost to follow-up. At the age of 15 years she was admitted with similar but milder complaints, including attacks of abdominal pain, diarrhea and flatulence. At this time, the attacks were less frequent (every 2-3 months) and the duration was shorter (1-2 days), but they were still accompanied by fever and joint pain. Her body weight and height were between the 10th and 25th percentiles for her age, and physical examination and vital signs were normal. Urine analysis showed massive proteinuria $\left(500 \mathrm{mg} / \mathrm{dL}, 79 \mathrm{mg} / \mathrm{m}^{2} / \mathrm{h}\right)$, with serum total protein and albumin levels of 6.9 and $3.9 \mathrm{~g} / \mathrm{dL}$, respectively.

\section{Questions}

1. What could be the reason for the proteinuria?

2. Which additional steps would you take to arrive at a diagnosis? 